\title{
26. Mitotic Activity in Vaginal Epithelium in Neonatally Androgenized Mice Following Estrogen Administration*)
}

\author{
By Taisen IguchI \\ Department of Biology, Faculty of Science, Okayama University, \\ Tsushima, Okayama 700 \\ (Communicated by Kiyoshi TAKEWAKI, M. J. A., June 14, 1977)
}

In ovariectomized adult mice which had been given neonatal injections of adequate doses of estrogen or androgen, estrogenindependent persistent proliferation and cornification occur in the vaginal epithelium (for review, see Takasugi, 1976). Moreover, in neonatally estrogenized mice, response of the vaginal epithelium to postpuberal administration of estrogen is permanently affected, as evidenced by a definite reduction in number of mitotic figures in the epithelium after treatment (Mori, 1967, 1968, 1969).

The present experiments were designed to study the response of uterine and vaginal epithelial cells to estrogen in neonatally androgenized, ovariectomized adult mice.

Materials and methods. Thirty-eight female mice of the C57Black/Tw strain were injected subcutaneously with $5 \mu \mathrm{g}$ (Group II, $\mathrm{n}=14$ ), $25 \mu \mathrm{g}$ (Group III, $\mathrm{n}=10$ ) or $50 \mu \mathrm{g}$ (Group IV, $\mathrm{n}=14$ ) $5 \alpha$ dihydrotestosterone propionate (DHTP) in $0.02 \mathrm{ml}$ sesame oil over 5 days from the day of birth. Ten mice receiving injections of oil vehicle only for the first 5 days of postnatal life served as controls (Group I). All mice were ovariectomized at 120 days of age. Half of the animals of each group were given daily injections of $1 \mu \mathrm{g}$ estradiol-17 $\beta\left(\mathrm{E}_{2}\right)$ in $0.2 \mathrm{ml}$ sesame oil from 177 to 179 days of age (Groups Ib, IIb, IIIb and IVb). The remaining mice were given injections of oil vehicle only prior to sacrifice (Groups Ia, IIa, IIIa and IVa). All animals were sacrificed 5 hours after a single injection of $0.1 \mathrm{mg}$ colchicine $/ 20 \mathrm{~g}$ body weight, dissolved in a $0.9 \% \mathrm{NaCl}$ solution, at 180 days of age. Vaginae and uteri were fixed in Bouin's fluid and cut into longitudinal or transverse sections in paraffin at $7 \mu \mathrm{m}$. Sections were stained with Delafield's hematoxylin and eosin. Dividing cells at metaphase per 200 basal cells were counted in 5 sections randomly taken of the uterine epithelium. Similar mitosis counts were carried out in the vaginal epithelium in the cervical,

*) Supported by a Grant-in-Aid for Fundamental Scientific Research from the Ministry of Education, Science and Culture, Japan, given to Prof. N. Takasugi. 
proximal (upper 3/5) and distal (lower 2/5, urethral and antiurethral sides) parts, separately.

Results. In 180-day-old, ovariectomized control mice, the vaginal epithelium was atrophic, consisting of 2-3 layers of cuboidal cells (Group Ia). By contrast, in mice given neonatal injections of DHTP (Groups IIa, IIIa and IVa), the epithelium lining the proximal part of vagina was composed of 4-10 layers of cells with a superficial layer consisting of either mucified or cornified (or parakeratotic) cells. The epithelium lining the cervical part was stratified with or without overlying mucous cells. The epithelium of the distal part consisted of 4-7 layers of cells without any specialized superficial layer, as reported previously (Iguchi and Takasugi, 1976; Ohta and Iguchi, 1976). The uterine epithelium of the ovariectomized control mice was composed of a single layer of low columnar cells. However, in one mouse from Group IIa and another from IVa, the uterine epithelium was stratified.

Three daily injections of $1 \mu \mathrm{g} \mathrm{E}_{2}$ invariably caused proliferation and cornification of the whole vaginal epithelium in ovariectomized control mice. In all DHTP-treated mice, the epithelium lining the cervical and proximal parts of vagina was proliferated and cornified. However, no superficial specialization took place in the epithelium lining the distal part. Uterine epithelium of mice given $\mathrm{E}_{2}$ injections prior to sacrifice was composed of a single layer of tall columnar cells in all the control and neonatally DHTP-treated mice except for one mouse from Group IIb and another from IVb showing squamous metaplasia.

Mitotic figures were seldom encountered in the uterine as well as vaginal epithelium of the control mice (Group Ia). However, estradiol administration prior to sacrifice invariably caused an elevation of the mitotic rate in all parts of the uterine and vaginal epithelium (Group Ib). Mitotic rates of the uterine and vaginal epithelia were significantly higher in neonatally DHTP-treated mice than in the controls. Following 3 daily injections of $\mathrm{E}_{2}$ in the DHTP-treated mice, a significant rise in the mitotic rate occurred in epithelial cells in the uterus (Group IVb), and the cervical (Groups IIb, IIIb and IVb), proximal (Group IIb) and the distal parts of vagina of Groups IIb and IIIb. There was no significant rise in mitotic rate in epithelial cells lining the uterus of Groups IIb and IIIb, the proximal part of vagina of Groups IIb and IVb and the distal part of vagina of Group IVb (Table I).

Uteri were heavier in the DHTP-treated mice (Groups IIIa and IVa) than in the controls (Group Ia). Uterine weight was markedly increased by $\mathrm{E}_{2}$ administration in all groups, especially in Groups 
Table I. Mitotic rates (\%) in the basal layer of the vaginal and uterine epithelia in normal and neonatally DHTP-treated, ovariectomized adult mice

\begin{tabular}{|c|c|c|c|c|c|}
\hline \multirow{3}{*}{ Group } & \multirow{3}{*}{$\begin{array}{l}\text { Uterine } \\
\text { epithelium }\end{array}$} & \multicolumn{4}{|c|}{ Vaginal epithelium } \\
\hline & & \multirow{2}{*}{$\begin{array}{c}\text { Cervical } \\
\text { part }\end{array}$} & \multirow{2}{*}{$\underset{\text { part }}{\text { Proximal }}$} & \multicolumn{2}{|c|}{ Distal part } \\
\hline & & & & $\begin{array}{l}\text { anti-urethral } \\
\text { side }\end{array}$ & $\begin{array}{l}\text { urethral } \\
\text { side }\end{array}$ \\
\hline Ia $(5)^{*}$ & $0.05 \pm 0.01 * *$ & $0.1 \pm 0.03$ & $0.2 \pm 0.04$ & $0.2 \pm 0.03$ & $0.1 \pm 0.02$ \\
\hline $\mathrm{E}_{2} \mathrm{Ib}$ & $0.42 \pm 0.13$ & $3.3 \pm 0.27$ & $4.9 \pm 0.50$ & $3.8 \pm 0.28$ & $3.1 \pm 0.17$ \\
\hline IIa (7) & $0.55 \pm 0.14$ & $0.7 \pm 0.08$ & $2.1 \pm 0.17$ & $0.8 \pm 0.09$ & $0.4 \pm 0.04$ \\
\hline $\mathrm{E}_{2} \quad \mathrm{IIb} \quad(7)$ & $0.441+0.16$ & $2.6 \pm 0.28$ & $4.1 \pm 0.20$ & $3.4 \pm 0.19$ & $0.7 \pm 0.07$ \\
\hline $\operatorname{IIIa}(5)$ & $0.58 \pm 0.21$ & $0.6 \pm 0.08$ & $2.6 \pm 0.39$ & $0.6 \pm 0.11$ & $0.3 \pm 0.09$ \\
\hline $\mathrm{E}_{2} \quad \operatorname{IIIb}(5)$ & $0.32 \pm 0.14$ & $2.7 \pm 0.31$ & $4.1 \pm 0.53$ & $2.4 \pm 0.55$ & $0.9 \pm 0.05$ \\
\hline IVa (7) & $0.36 \pm 0.06$ & $0.8 \pm 0.15$ & $3.0 \pm 0.36$ & $0.6 \pm 0.24$ & $0.3 \pm 0.08$ \\
\hline $\mathrm{E}_{2} \quad \mathrm{IVb}(7)$ & $0.84 \pm 0.18$ & $2.9 \pm 0.37$ & $2.3 \pm 0.26$ & $1.0 \pm 0.14$ & $0.5 \pm 0.11$ \\
\hline $\begin{array}{l}\text { Ia }: \text { Ib } \\
\text { IIa }: \text { IIb } \\
\text { IIIa }: \text { IIIb } \\
\text { IVa }: \text { IVb }\end{array}$ & $\begin{array}{l}\mathrm{p}<0.001 \\
\left\{\mathrm{NS}^{* * * *}\right. \\
\mathrm{p}<0.05\end{array}$ & $p<0.001$ & $\left\{\begin{array}{l}\mathrm{p}<0.001 \\
\mathrm{NS}\end{array}\right.$ & $\begin{array}{l}p<0.001 \\
p<0.01 \\
\text { NS }\end{array}$ & $\begin{array}{l}\mathrm{p}<0.001 \\
\mathrm{p}<0.02 \\
\mathrm{p}<0.001 \\
\text { NS }\end{array}$ \\
\hline
\end{tabular}

* No. of mice. ** Mean \pm S.E. *** Statistically non-significant.

IIIb and IVb. There was no significant difference in vaginal weight between DHTP-treated mice and the controls. However, the weight was considerably increased by $\mathrm{E}_{2}$ injections in both the control and neonatally DHTP-treated mice (Groups IIb and IIIb) except for Group IVb (Table II).

Table II. Organ weights in normal and neonatally DHTP-treated, ovariectomized adult mice

\begin{tabular}{|c|c|c|c|c|c|}
\hline \multirow{3}{*}{\multicolumn{2}{|c|}{ Group }} & \multicolumn{4}{|c|}{ Weight (mg)/20 g body weight } \\
\hline & & \multicolumn{2}{|c|}{ Uterus } & \multicolumn{2}{|c|}{ Vagina } \\
\hline & & Oil (a) & $\mathrm{E}_{2}(\mathrm{~b})$ & Oil (c) & $E_{2}(d)$ \\
\hline \multicolumn{2}{|r|}{ I } & $7.5 \pm 1.61 *$ & $50.6 \pm 3.97$ & $20.5 \pm 1.59$ & $45.2 \pm 3.27$ \\
\hline \multicolumn{2}{|r|}{ II } & $13.8 \pm 2.56$ & $55.9 \pm 4.17$ & $16.1 \pm 3.07$ & $29.5 \pm 0.81$ \\
\hline \multicolumn{2}{|r|}{ III } & $15.5 \pm 1.58$ & $103.3 \pm 11.58$ & $20.9 \pm 1.00$ & $30.1 \pm 2.78$ \\
\hline \multicolumn{2}{|r|}{ IV } & $18.1 \pm 1.16$ & $87.0 \pm 6.90$ & $23.0 \pm 2.94$ & $27.7 \pm 1.87$ \\
\hline & : II & NS** & NS & & $\mathrm{p}<0.002$ \\
\hline & : III & $\mathrm{p}<0.05$ & $\ln <0$ & $\mathrm{NS}$ & $\mathrm{p}<0.05$ \\
\hline & : IV & $\mathrm{p}<0.001$ & $\{\mathrm{p}<0.002$ & & $\mathrm{p}<0.002$ \\
\hline
\end{tabular}

IIc : IId $\mathrm{p}<0.002$, IIIc : IIId $\mathrm{p}<0.02$, IVc : IVd $\mathrm{p}>0.5$ (NS).

* Mean土S.E. ** Statistically non-significant. 
Discussion. In ovariectomized adult mice treated neonatally with $5 \mu \mathrm{g}$ DHTP, 3 daily injections of $\mathrm{E}_{2}$ given postpuberally brought about a significant rise in mitotic rate throughout the vaginal epithelium. However, similar injections of $\mathrm{E}_{2}$ induced no significant rise in mitotic rate in the epithelium lining the vagina, except for the cervical part, in animals given injections of $50 \mu \mathrm{g}$ DHTP for 5 neonatal days. The present findings indicate that in mice receiving neonatal injections of high doses of DHTP, the vaginal epithelium becomes less sensitive to postpuberal $\mathrm{E}_{2}$ administration. Low doses of DHTP injected neonatally were less effective in lowering vaginal sensitivity to $\mathrm{E}_{2}$. The mitotic rate in the epithelium of the distal part of vagina was lower than in the proximal part in all DHTP-treated groups. Moreover, the urethral side of the distal part of vagina of such mice, the mitotic activity was always lower than in the antiurethral side. These findings are in harmony with the previous findings that the vaginal epithelium failed to mucify following treatment with $\mathrm{E}_{2}$ plus progesterone in neonatally androgenized mice (Ohta and Iguchi, 1976).

Acknowledgements. Purified $5 \alpha$-dihydrotestosterone propionate prepared by Dr. H. Mori of Teikoku Zoki Pharmaceutical Co. was given to the author by Emeritus Prof. K. Takewaki of Tokyo University to whom his sincere thanks are due. The author wishes to thank Prof. N. Takasugi for his guidance and valuable advice.

\section{References}

Iguchi, T., and N. Takasugi (1976) : Endocr. Japon., 23, 327.

Mori, T. (1967) : Annot. Zool. Japon., 40, 82.

- (1968) : Proc. Japan Acad., 44, 516.

- (1969) : Ibid., 45, 931.

Ohta, Y., and T. Iguchi (1976) : Endocr. Japon., 23, 333.

- (1976) : Proc. Japan Acad., 52, 583.

Takasugi, N. (1976) : Internat. Rev. Cytol., 44, 193. 